\title{
Studi Deskriptif Eksistensial pada Penderita Penyakit Kronis (Kanker)
}

\section{(Existential Descriptive Study In Patients With Chronic Disease (Cancer))}

\author{
Rr Atika Widya Utama ${ }^{1}$, Muhamad Uyun ${ }^{1}$, Eko Oktapiya Hadinata ${ }^{1}$ \\ Fakultas Psikologi, Universitas Islam Negeri Raden Fatah Palembang \\ muhamaduyun_uin@radenfatah.ac.id
}

\begin{abstract}
Abstrak
Penelitian ini bertujuan untuk mengetahui bagaimana gambaran eksistensial pada penderita penyakit kronis dalam hal ini kanker. Penelitian ini adalah penelitian kualitatif deskriptif yang bertujuan untuk memberikan deskripsi mengenai studi deskriptif eksistensial pada penderita penyakit kronis (kanker). Berdasarkan hasil penelitian dapat disimpulkan bahwa tidak semua orang yang mengidap penyakit kronis dalam hal ini kanker akan kehilangan eksistensinya dalam waktu yang panjang, hal ini dapat diatasi dengan memberikan terapiutik dan juga peran serta dukungan dari keluarga untuk penderita kanker.
\end{abstract}

Kata kunci: Eksistensial, Kanker, Terapiutik

\begin{abstract}
This study aims to discuss how existential in patients with chronic diseases in this case cancer. This study is a descriptive qualitative research which aims to provide a description of existential descriptive studies in patients with chronic disease (cancer). Based on the results of the study it can be concluded that not everyone who has a chronic disease in this case the cancer will lose its existence in a long time, this can be overcome by providing therapy and also the role and support of families for cancer sufferers.
\end{abstract}

Keywords: Existential, Cancer, Therapeutic

\section{Pendahuluan}

"Mensana in Corporesano", yang berarti "dalam tubuh yang sehat terdapat jiwa yang kuat", pernyataan ini sudah dikenal oleh banyak orang sejak lama dan terbukti benar karena orang yang rutin berolahraga akan memiliki tubuh yang sehat dan bugar serta kesehatan yang terjaga, mereka dapat melakukan aktivitas sehari-hari dengan baik, bersemangat, tidak cepat lelah dan tidak mudah sakit. Salah satu keniscayaan pada manusia adalah terserang penyakit. Penyakit bisa datang dimana saja, kapan saja dan pada siapa saja. Oleh karena itu, manusia harus bisa semaksimal mungkin menjaga kesehatan. Kondisi sehat dapat dipertahankan karena individu mempunyai ketahanan tubuh yang baik. Bukan hanya itu saja, bajkan penyakit kronis bisa datang karena adanya perubahan pada fungsi fisiologis, psikologis, kognitif, emosi dan perilaku individu tersebut. Singkatnya, penyakit kronis adalah penyakit yang diderita selama bertahun-tahun dan tidak sembuh serta mengalami kerusakan saraf dan organ (Matsumoto, 2009; Wong, 2009). Selaras dengan apa yang dikemukakan oleh Adelman dan Daly (2001) bahwa, penyakit kronis merupakan penyakit yang lama dalam penyembuhannya, diseases that take a long time, don't occur suddenly oe spontaneously, and usually can't be cured completely. Chronic illness is closely related to disability and the onset of death. 
WHO melaporkan kondisi global mengenai penyakit-penyakit tidak menular dari tahun 2000 hingga 2015 yang mengakibatkan 80 persen kematian. Delapan puluh persen dari kematian itu terjadi di negara-negara berkembang, termasuk Indonesia. Sehingga negara-negara ini mengeluarkan milyaran dolar untuk mengobati penyakit-penyakit seperti kanker, sakit jantung, dan diabetes (WHO, 2016). Ada beberapa hasil penelitian tentang kondisi penderita penyakit kronis diantaranya; Mery Agustini (2016) bahwa para penderita penyakit jantung koroner memiliki rasa takut, tergoncang jiwanya, cemas, gelisah, resah, takut, putus asa serta merasa kebingungan untuk melakukan apa untuk kedepannya setelah mengalami penyakit tersebut. Penyakit kronis merupakan jenis penyakit degeneratif yang berkembang atau bertahan dalam jangka waktu yang sangat lama, yakni lebih dari enam bulan. Orang yang menderita penyakit kronis cenderung memiliki tingkat kecemasan yang tinggi dan cenderung mengembangkan perasaan hopelessness dan helplessness karena berbagai macam pengobatan tidak dapat membantunya sembuh dari penyakit kronis (Sarafino, 2006). Menurut Christensen (2006) ada beberapa kategori penyakit kronis, yaitu seperti lived with illnesses, mortal illnesses, dan at risk illnesses. Lived with illnesses, pada kategori ini individu diharuskan beradaptasi dan mempelajari kondisi penyakitnya selama hidup dan biasanya tidak mengalami kehidupan yang mengancam. Penyakit yang termasuk dalam kategori ini adalah diabetes, asma, arthritis, dan epilepsi. Mortal illnesses, pada kategori ini secara jelas kehidupan individu terancam dan individu yang menderita penyakit ini hanya bisa merasakan gejala-gejala penyakit dan ancaman kematian. Penyakit dalam kategori ini adalah kanker dan penyakit kardiovaskuler. At risk illnesses, kategori penyakit ini sangat berbeda dari dua kategori sebelumnya. Pada kategori ini tidak ditekankan pada penyakitnya, tetapi pada risiko penyakitnya. Penyakit yang termasuk dalam kategori ini adalah hipertensi dan penyakit yang berhubungan dengan hereditas.

Sekarang ini pencegahan penyakit diartikan secara luas. Dalam pencegahan penyakit dikenal pencegahan primer, sekunder, dan tersier (Djauzi, 2009). Pencegahan primer merupakan upaya untuk mempertahankan orang yang sehat agar tetap sehat atau mencegah orang yang sehat menjadi sakit. Pencegahan sekunder merupakan upaya untuk menghambat progresivitas penyakit, menghindari komplikasi, dan mengurangi ketidakmampuan yang dapat dilakukan melalui deteksi dini dan pengobatan secara cepat dan tepat. Pencegahan tersier dimaksudkan untuk mengurangi ketidakmampuan dan mengadakan terapi, contohnya terapi eksistensial (Budiarto \& Anggreni, 2007). Seperti hasil penelitian tentang memiliki mimpi masa depan yang hancur karena diagnosis kanker. Beberapa dari blogger mengungkapkan ini sebagai kehilangan keabadian yang dirasakan pemuda blogger yang mengidap sakit kanker, dengan menyadari bahwa kehidupan mereka tiba-tiba memiliki akhir yang terlihat terlalu cepat dan bahwa ada kematian menunggu bahkan untuk mereka. Hal ini membuat mereka berbicara tentang ketidakpastian, ketakutan dan kecemasan tentang masa depan yang akan dihadapi. Mereka menggambarkan hal ini sebagai kehilangan masa depan mereka (Udo, 2014). Penelitian tersebut berbeda dengan hasil wawancara awal yang dilakukan ke subjek FN (18 Juni 2017) yang menderita penyakit kanker tiroid stadium 1, FN menyatakan bahwa sampai sekarang masih bisa beraktifitas seperti biasanya, tidak ingin berpikir bahwa karena sakit akan menjadikan pribadi yang tidak bisa melakukan segala hal yang ingin dia lakukan, karena menurutnya sakit bukanlah alasan untuk meratapi diri dan membuatnya menjadi orang yang tidak bisa apa-apa. Hal ini juga dibantu oleh orang-orang disekitarnya baik itu keluarga maupun sahabat terdekatnya yang selalu memberinya motivasi, dukungan dan mereka juga tidak mengganggap FN layaknya orang yang terkena sakit kronis, seperti kutipan wawancara FN:

"Nah dengan kita melakukan aktivitas seperti biasanya dan malah memperbanyak aktivitas kita, secara tidak langsung kita terlupa dari sakit itu. Alhamdulilahnya keluarga, sahabat dan orang-orang disekitar aku ini semuanya ngerti, mereka tuh gak pernah ya kayak menunjukkan atau memperlakukan aku tu seperti orang yang emang sedang sakit".

Pernyataan di atas diperkuat dengan hasil observasi penulis selama melakukan wawancara, saat melakukan sesi wawancara tersebut terlihat bahwa subjek FN terlihat bersemangat dan sebelum wawancara berlangsung subjek terlihat sedang mengerjakan skripsinya, dan tampak pula pada wajah subjek tidak terlihat pucat dan sering bercanda selama wawancara berlangsung. Dan hasil wawancara terhadap SN (22 Juni 2017), subjek berusia 47 tahun dan menderita kanker cervical stadium 2, SN menyatakan bahwa penyakit itu tidak boleh dimanja, jangan karena sakit menjadikan seseorang yang 
tidak berdaya yang hanya bisa duduk, berbaring, makan, diam, duduk dan berbaring lagi. Lebih baik sakit itu dibawa kerja sehingga ketika banyak aktivitas maka semakin lupa akan penyakit yang ada:

"Kalau kita cuma ngeluh sakit sakit bae tapi tidak ada tindakan, cuma diem berbaring dirumah yang ada juga makin sakit, kalau beraktivitas, banyak kegiatan kan banyak teman ngobrol bercanda secara tidak langsungkan lupa bahwa sedang sakit”.

Apa yang dikemukakan di atas selaras dengan hasil observasi kepada subjek selama proses wawancara, saat melakukan sesi wawancara terlihat subjek masih bersemangat mengerjakan pekerjaannya, tidak ada terdengar subjek mengeluh karena sakitnya. Hal ini dikarenakan salah satu faktor dari metode being in the world dari Rollo May yaitu Milwelt bahwa manusia juga membutuhkan orang lain dan hubungan sosial untuk membuat dirinya lebih dari sakit yang dideritanya dan yang mampu mendorong kesembuhan seorang pasien seperti ditentukan kemampuan relasi dokter, perawat, keluarga, maupun lingkungan sekitar dalam menjalankan proses kesembuhan seorang pasien, terutama dalam hal kemampuan komunikasi interpersonal (Stuart \& Sundeen, 1991). Ketika dihadapkan dengan diagnosis penyakit serius, banyak orang bergumul dengan masalah emosional dan eksistensial. Saat hari-hari di isi dengan perawatan dan kunjungan kesehatan, peran pasangan, orang tua, atau pekerja dapat memberi jalan bagi pasien. Sebagai hasilnya, banyak yang hidup dengan penyakit serius melaporkan keinginan untuk menegaskan aspek lain dari kehidupan mereka yang tidak terkait dengan fungsi fisik. Seperti meninjau kembali kekuatan pribadi, mengejar kegiatan yang memberi makna pada hidup, berkontribusi pada orang lain dan mencapai tujuan yang penting. Komunikasi interpersonal merupakan komponen terpenting dalam proses kesembuhan. Dokter, keluarga maupun orang terdekat yang dapat memahami masalah pasien secara komprehensif, sehingga, pelayanan kesehatan dapat dilakukan secara menyeluruh seperti melalui terapiutik.

Terapiutik merupakan hubungan interpersonal antara konselor, keluarga dengan klien, dalam hubungan ini konselor atau orang terdekat pasien dan pasien itu sendiri memperoleh pengalaman belajar bersama dalam rangka memperbaiki pengalaman emosional dari pasien itu sendiri (Stuart \& Sundeen, 1991). Sehingga, saat subjek mengetahui hasil diagnosa, yang bagi mereka adalah kabar buruk dalam kehidupan karena akan berhadapan dengan kematian yang pada akhirnya hal-hal negatif seperti, putus asa, sedih dan merasakan kekhawatiran hadir di jiwanya. Oleh karena itu, untuk mengembalikan rasa percaya diri, dan eksistensi diri pada pasien, terapiutik dapat menjadi rujukan bagi pasien. Dalam prosesnya, terapiutik merupakan proses komunikasi yang direncanakan secara sadar, bertujuan dan kegiatannya dipusatkan untuk kesembuhan pasien (Indrawati, 2003). Selaras dengan apa yang dikemukakan oleh Pieter (2007) bahwa terapiutik adalah komunikasi yang memiliki makna tersendiri bagi pasien dan dilakukan oleh terapis untuk membantu pasien mencapai kondisi yang sehat, adaptif dan positif. Singkatnya, terapiutik merupakan terapi yang alur utamanya adalah komunikasi, membangun komunikasi dengan baik antara terapis dengan pasien yang disertai dengan kesadaran. Beda halnya dengan eksistensial, namun memiliki keterkaitan antar keduanya. Menurut Chaplin (2000) eksistensial merupakan cara pandang manusia terhadap dirinya sendiri, kebebasan dalam memilih tujuan hidup dan berusaha memahami arti hidup itu sendiri. Sehingga, pemahaman yang utuh sekaligus kebebasan yang ada memiliki peran positif bagi manusia, khususnya penderita penyakit kronis yang setidak-tidaknya mampu menghadapi setiap kegelisahan bahkan, kekhawatiran dalam menjalani kehidupan di masa datang. Oleh sebab itulah, peran terapiutik adalah jalan bagi penderita penyakit kronis dalam membantu menemukan makna hidup yang sempat hilang dalam dirinya. Dengan demikian, berdasarkan latar belakang masalah di atas, maka diperlukan kajian lebih dalam tentang "Studi Deskriptif Eksistensial Pada Penderita Penyakit Kronis Kanker".

\section{Metode Penelitian}

Penelitian ini-menggunakan metode penelitian kualitatif dengan model penelitian deskriptif, untuk melihat bagaimana eksistensial diri pada penderita penyakit kronis kanker. Menurut Herdiansyah (2014) penelitian kualitatif adalah suatu penelitian ilmiah yang bertujuan untuk memahami suatu fenomena dalam konteks sosial secara alamiah dengan mengedepankan proses interaksi komunikasi yang mendalam antara peneliti dengan fenomena yang diteliti. Sedangkan model 
penelitian deskriptif adalah suatu model penelitian yang bertujuan untuk memberikan deskripsi mengenai apa yang diteliti (Herdiansyah, 2015). Penelitian ini menggambarkan suatu situasi atau kejadian. Data yang dikumpulkan semata-mata bersifat deskriptif sehingga tidak bermaksud mencari penjelasan, menguji hipotesis, membuat prediksi, maupun mempelajari implikasi (Azwar, 1998).

Teknik yang digunakan untuk menentukan subjek dalam penelitian ini dipilih melalui teknik purposeful sampling. Purposeful sampling adalah teknik memilih subjek dengan ciri-ciri yang sesuai dengan tujuan penelitian yang akan dilakukan (Herdiansyah, 2014). Ada tiga ciri dalam memilih subjek penelitian ini; pertama, subjek yang mengidap penyakit kronis kanker. Kedua, memiliki kesibukan dan masih dijalaninya seperti, kuliah dan bekerja. Ketiga, mampu berkomunikasi dengan baik. Metode pengumpulan data dalam penelitian ini adalah observasi, wawancara, dan dokumentasi. Sedangkan metode analisis data dalam penelitian ini adalah Miles \& Huberman. Tahapan dalam penelitian ini adalah metode analisis data Miles \& Huberman terdiri dari tahapan pengumpulan data, reduksi data, serta display \& verification. Keabsahan data pada penelitian ini adalah metode triangulasi data, tepatnya, data triangulation yang menggunakan lebih dari satu metode pengumpulan data seperti, wawancara, observasi dan dokumentasi.

\section{Hasil Penelitian dan Pembahasan}

Penelitian ini membahas tentang eksistensial diri untuk masing-masing subjek yang terdiagnosa penyakit kanker di kota Palembang, dengan subjek berjumlah 2 orang perempuan. Satu merupakan penderita kanker tiroid dan satunya lagi menderita kanker endometrium. Dilihat dari deskripsi latar belakang dan kegiatan sehari-hari subjek saat ini yaitu, pada subjek FN menderita kanker tiroid di umurnya yang masih muda yaitu 21 tahun sedangkan subjek SN menderita kanker endometrium di usia 46 tahun. Setiap subjek memiliki kegiatan yang berbeda, FN sekarang bekerja di salah satu bank milik negara dan bekerja pada hari Senin sampai dengan Jumat. Diwaktu luangnya FN menggunakan waktunya untuk berkumpul bersama keluarga dan teman-temannya. Sedangkan SN memilih untuk menjadi ibu rumah tangga untuk lebih fokus mengurus suami dan anak-anaknya, untuk mengisi waktu luangnya SN memilih untuk melanjutkan kegiatannya sebelum didiagnosa kanker yaitu menjahit, SN menerima pesanan jika ada orang yang ingin menempa jahitan baju ataupun celana. Setiap subjek memiliki gejala yang berbeda-beda, pada diri FN misalnya, merasa tidak ada sakit dalam dirinya, dia merasa bahwa dirinya dalam keadaan sehat tetapi FN merasa sangat mudah lelah dan mudah sekali pingsan jika sudah merasa lelah dan memiliki tremor yang susah untuk dikontrol atau dihentikan serta terdapat benjolan di lehernya yang semakin hari semakin membesar dan mengganggu aktivitasnya. Sedangkan SN, SN merasakan nyeri pada pinggulnya dan mengalami pendarahan pada rahimnya.

Orang yang terkena penyakit kronis dan orang tersebut mengetahui bahwa penyakit itu sulit dan hampir tidak dapat disembuhkan maka ia akan merasakan ketakutan, putus asa, dan ketidak bermaknaan dalam hidupnya, karena yang terfikir olehnya hanya kematian (Jones,2006). Selaras dengan penelitian yang dilakukan oleh Thorolless dkk (2017) bahwa ketika pasien mengetahui bahwa dia menderita penyakit kanker dan mencapai lebih ekstrim tingkat gangguan fisik dan munculnya depresi, mereka merasakan bahwa kematian sekarang sudah dekat. Pada pasien wanita mendapat skor lebih tinggi dalam keinginan cepat mengakhiri hidup dan tingkat depresi yang tinggi. Hal ini selaras dengan gambaran kedua subjek yaitu FN dan SN. Ketika mengetahui bahwa mereka terdiagnosa penyakit dan sakit itu salah satu penyakit yang sangat mematikan yaitu kanker, merasakan bahwa kematian itu sudah berada di depan dan merasa putus asa, sedih dan merasakan ketakutan dalam hidupnya. Kesulitan mendalam dalam hal penderitaan psikososial pada mereka dengan penderita kanker harus dicocokkan dengan perawatan psikososial yang sama efektif dan intervensi terapeutik. Kekhawatiran eksistensial, kehilangan, dan kesedihan adalah teman-teman yang sering dijumpai pada pengalaman onkologi, dan tidak boleh dilupakan baik dalam domain klinis atau empiris dari onkologi psikososial (Tacon, 2011). Pada dasarnya orang- orang yang menderita sakit akan mengalami kesulitan dalam beraktivitas karena merasa dirinya tidak mampu untuk melakukan hal itu, lama kelamaan itu akan menjadi syndrome untuk sendiri, adanya ketakutan penyakitnya semakin menjadi dan ketidak sanggup untuk menahan rasa sakit yang mereka rasakan (Tooket, 2018). Setelah itu lama kelamaan 
mereka secara tidak langsung akan kehilangan eksistensi dari diri sendiri karena rasa takut yang ada pada diri mereka untuk melakukan sesuatu yang bisa membuat mereka menjadi semakin merasa kesakitan.

Pengobatan yang didapatkan oleh kedua subjek berbeda. Pada FN, FN sudah melakukan operasi tiga kali untuk pengangkatan tiroidnya dan diberikan obat untuk penstabilan tubuhnya sedangkan SN hanya diberikan obat-obatan saja tanpa melakukan operasi maupun radiasi. Namun pada kedua subjek sama-sama diberikan terapiutik untuk mengembalikan eksistensi mereka. Hierarki kebutuhan Maslow, merupakan salah satu teori motivasi paling terkenal. Hierarki lima tingkat yang terdiri atas kebutuhan fisiologis, rasa aman, cinta, penghargaan, dan mewujudkan jati diri (Maslow, 1970). Untuk mewujudkan semua kebutuhan pada kedua subjek ini membutuhkan motivasi dari keluarga dan kerabat terdekat mereka. Peran keluarga sangat penting bagi mereka untuk bisa mewujudkan semua kebutuhan itu untuk mencapai kebutuhan paling puncak. Karena ketika dihadapkan dengan diagnosis penyakit serius, banyak orang bergumul dengan masalah emosional dan eksistensial. Saat hari-hari diisi dengan perawatan dan kunjungan kesehatan, peran pasangan, orang tua, atau pekerja dapat memberi jalan bagi pasien dan bermanfaat bagi kesehatan mereka.

Pasien yang menderita penyakit serius mengalami tingkat kecemasan dan depresi yang tinggi sehingga mereka akan kehilangan eksistensi yang ada pada diri mereka. Dalam Kamus Psikologi, depresi adalah suasana hati yang dicirikan perasaan tidak nyaman, sebuah perasaan murung, sebuah penurunan di dalam aktivitas maupun reaktivitas, pesimisme, kesedihan dan simtom-simtom terkait (Reber, 2010). Dalam intervensi yang membahas kebutuhan eksistensial dapat memeriksa hasil seperti rasa ketahanan, kesadaran pribadi, pandangan tentang penyakit, atau perjuangan spiritual atau lebih halus lainnya. Dalam hal ini pasien sangat membutuhkan terapi yang bisa mengembalikan eksistensinya, hanya menggunakan meditasi relaksasi, dalam populasi orang dewasa dengan penyakit lanjut tidak menghasilkan efek yang signifikan (Steinhauser, 2017). Pencapaian spiritual kadang-kadang dibahas dalam psikoterapi bersama dengan perhatian, tetapi umumnya, perhatian digunakan untuk membantu orang mendapatkan kesadaran dan wawasan tentang masalah lain. Dalam psikoterapi, perhatian digunakan untuk mendukung tujuan, mengurangi stres, membantu mencegah kekambuhan, atau mencapai tujuan lain. Sedangkan pada praktek mindfulness adalah tambahan yang kuat untuk pendekatan eksistensial untuk psikoterapi yang mendukung introspeksi dan pengenalan diri (Harris, 2013). Namun pada kedua subjek ini sama-sama diberikan terapiutik untuk pengembalian eksistensi mereka. Hanya bedanya pada subjek SN diberikan terapiutik oleh dokter serta perawat yang merawatnya selama di rumah sakit, sedangkan FN diberi terapiutik dari sang ibu yang kebetulan berprofesi sebagai perawat disalah satu rumah sakit dan metode terapiutik dilakukannya di rumah. Terapiutik ini diberikan sesuai dengan tujuan terapiutik itu sendiri yaitu meluaskan kesadaran diri klien, dan karenanya meningkatkan kesanggupan pilihannya, yakni menjadi bebas dan bertanggung jawab atas arah hidupnya (Corey, 2013). Dalam proses terapiutik semua dokter atau terapis harus dapat melakukan psikoterapi suportif seperti katarsis, persuasif, sugesti, penjamin kembali, bimbingan dan penyuluhan (Fithriyah dan Jauhar, 2014).

Hal-hal ini dilakukan oleh dokter atau terapis yang memberikan terapi kepada kedua subjek untuk pengembalian eksistensi mereka. Terapiutik ini juga sudah mencakup hampir semua hal yang bisa membantu mengembalikan eksistensial seseorang. Terapiutik bisa saja dilakukan secara individu atau dengan diri sendiri namun tidak mempengaruhi secara signifikan kurva kelangsungan hidup, karena ada hambatan untuk terjemahan klinis dari pendekatan konseptual penderita kanker, sehingga individu akan membutuhkan orang lain yang bisa menerjemahkan tentang terjemahan klinis yang dia hadapi (Shen, 2005). Namun pada penelitian yang dilakukan Piroth dkk, dia melihat bahwa penilaian pasien terhadap uji coba terapeutik tampaknya tidak terkait dengan status kesehatan individu, tidak semua pasien berfikir bahwa terapiutik dapat membantu mereka mengembalikan eksistensi mereka. Ada dua jenis pasien, pasien yang bersikap positif dan pasien yang bersikap negatif. Para pasien dengan sikap positif terhadap uji terapeutik untuk terapiutik ini dan menilai bahwa terapiutik ini bermanfaat untuk mereka dan bisa mebantu mereka menemukan eksistensinya lagi. Sedangkan pasien yang bersikap negatif, mereka berasumsi bahwa terapiutik ini tidak menguntungkan mereka. Namun kesimpulannya, sebagian besar pasien akan mendapat manfaat atau setidaknya tidak akan dirugikan oleh keterlibatan mereka dalam uji coba terapeutik (Piroth, 2015). Secara empiris menunjukkan bahwa 
terapeutik yang meningkat secara signifikan yang berasal dari mengadaptasi mitos pengobatan yang mendasarinya ke pandangan dunia budaya klien. Terapis dan konselor dapat memperluas kemampuan mereka untuk memasuki realitas subjektif dari orang yang ada di hadapan mereka dan untuk mengeksplorasi bersama mereka, daripada menggunakan teori dan model untuk menyesuaikan klien ke dalam pandangan mereka sendiri tentang dunia (Wilson \& Apple, 2013).

Kedua subjek sudah menemukan eksistensi mereka kembali dimana terlihat kedua subjek sudah bisa melakukan aktivitas mereka seperti semula, yang mana pada awalnya FN sempat tidak mau meneruskan kuliahnya dan tidak mau keluar dari rumah. Namun sekarang FN sudah menyelesaikan kuliahnya dengan baik bahkan FN sekarang bekerja menjadi pegawai bank di salah satu bank di Indonesia. Subjek SN yang awalnya mengetahui penyakit yang dia derita memilih untuk tidak melanjutkan hobinya yang selama ini dia kerjakan sehari-hari yaitu menjahit karena dia merasa bahwa dia sudah tidak sanggup lagi mengerjakan pekerjaan itu, namun akhirnya sekarang SN sudah bangkit dan mau beraktivitas seperti biasanya SN merawat suami dan anak-anaknya serta SN mencari kesibukan kembali dalam kesehariannya dan SN memilih untuk kembali menerima pesanan menjahit baju dan celana dirumahnya dan mendapatkan tambahan biaya untuk penggobatannya. Terbentuknya being in the world di dalam diri mereka tidak lepas dari being in the world yaitu Umwelt, Mitwelt, dan Eigenwelt (Feist-Feist, 2008). Miltwelt berarti hubungan individu dengan sosialnya, dan hal ini mereka mendapatkan dari terapiutik eksistensial yang diberikan oleh dokter, perawat serta keluarga yang merawat mereka.

Kedua subjek merasakan bahwa mereka juga merasa hidup mereka menjadi bermakna kembali ketika mereka bisa bangkit dari keterpurukannya ketika mengetahui bahwa mereka mengidap penyakit kanker serta ketika mereka bisa membuat orang-orang yang berada disekitarnya berbahagia untuk apa yang mereka lakukan ataupun mereka berbahagia atas mereka serta mereka bisa berbagi dengan sesama baik itu berbagi cerita, pengalaman yang mereka dapatkan. Masalah spiritual, eksistensial, dan psikologis merupakan komponen utama dari kualitas hidup seseorang untuk itu makna hidup bisa didapatkan ketika seseorang mendapatkan eksistensial dirinya kembali dan spiritualnya, jika penderita penyakit kronis ini tidak dapat mengembalikan eksistensial pada dirinya dan berkurangnya spiritual dalam dirinya maka makna dalam hidup mereka tidak terealisasikan, makna dalam kehidupan tampaknya menjadi faktor protektif potensial terhadap tekanan psikologis di akhir kehidupan (Bernard, 2017). Makna hidup dapat ditemukan dalam kehidupan itu sendiri, baik dalam keadaan yang menyenangkan dan tidak menyenangkan, keadaan bahagia, dan penderitaan. Bila hasrat ini dapat dipenuhi maka kehidupan akan dirasakan berguna, berharga dan berarti (meaningfull) akan dialami. Sebaliknya bila hasrat ini tidak terpenuhi akan menyebabkan kehidupan dirasakan tidak bermakna (meaningless), hampa dan tidak berguna (Frankl dalam Bastaman, 2007).

\section{Kesimpulan}

Berdasarkan hasil temuan dari penelitian dapat disimpulkan bahwa tidak semua orang yang terdiagnosa penyakit kronis dalam hal ini kanker akan merasakan keputusasaan yang berkepanjangan, hal ini dapat diatasi dengan memberikan terapiutik kepada penderita dan dukungan dari keluarga serta orang disekitarnya. Kedua subjek penelitian yaitu FN dan SN yang menderita penyakit kronis yaitu kanker, ketika mengetahui penyakit yang mereka derita mereka sempat kehilangan eksistensinya tetapi karena adanya dukungan keluarga dan orang sekitarnya serta diberikannya terapiutik kepada kedua subjek oleh para medis yang menanganinnya, nyatanya mereka bisa menemukan eksistensi dirinya kembali. Bahkan mereka menjadi orang yang lebih bersyukur dan lebih bersemangat dalam menjalani kehidupannya sekarang ini.

\section{Daftar Pustaka}

Abidin, Z. (2007). Analisis Eksistensial. Jakarta: PT.Raja Grafindo Persada.

Adelman, A.M \& Daly, M.P. (2001). Twenty Common Problems in Geriatrics. Singapore:McGraw- Hill Companies. 
Adz-Dzaky, H.B. (2001). Psikoterapi dan Konseling Islam: Penerapan Metode Sufistik. Yogyakarta: Fajar Pustaka Baru.

Agustini, M. (2016). Self-Efficacy Dan Makna Hidup Pada Penderita Penyakit Jantung Koroner. Samarinda: Ejournal Psikologi. Vol.4. No.4. 419-430.

Ahmadi, R. (2014). Metodologi Penelitian Kualitatif. Yogyakarta: Ar- Ruzz Media.

Al-Maraghiy, A.M. (1987). Tafsir Al-Maraghiy. Semarang: CV Toha Putra.

Astutik, S. (2012). Penanganan Psikopatologi Dengan Psikoterapi Islam. Jurnal Bimbingan dan Konseling Islam. Vol.2, No.1.

Azwar, Saifuddin. (1998). Metode Penelitian. Yogyakarta: Pustaka Pelajar.

Azwar, S. (2012). Reliabilitas dan Validitas. Yogyakarta: Pustaka Pelajar.

Bastaman, H.D. (2007). Logoterapi: Psikologi untuk Menemukan Makna Hidup dan Meraih Hidup Bermakna. Jakarta:PT Raja Grafinda Persada.

Bernard, M., Stasser, F., Gamondi, C., Braunschweig, G. (2017). Relationship between spirituality, meaning in life, psychological distress, wish for hastened death, and their influence on quality of life in palliative care patients: Journal of Pain and Symptom Management, 54 (4). 514522.

Browall, M. (2014). Existential encounters Nurses' descriptions of Critical Insidents in-end -of life cancer care. Europan Journal of Oncology. Nursing Vol. 18. 636-644.

Budiarto, E \& Dewi A. (2003). Pengantar Epidimiologi. Jakarta: EGC.

Chaplin, J. P. (2000). Kamus Lengkap Psikologi. Jakarta: Rajawali

Christensen, K. (2006). Adult Health Nursing, Ffth Edition. Philadelhia: Mosby Company.

Corey, G. (2013). Teori dan Praktek Konseling \& Psikoterapi. Bandung: Redaksi Refika.

Corwin, E.J. (2009). Buku Saku Patofisiologi (Edisi 3). Jakarta : EGC.

Creswell, J.W. (2012). Research Design pendekatan Kualitatif, Kuantitatif dan Mixed. Yogyakarta: Pustaka Pelajar.

Departemen Pendidikan Nasional. (2005). Kamus Besar Bahasa Indonesia. Edisi Ketiga. Jakarta: Balai Pustaka.

Djauzi, S. \& Zubairi, D. (2009). Buku Ajaran Ilmu Penyakit Dalam, Edisi Kelima, Jilid III. Jakarta: Internal Publishing.

Donsu, J.D.T. (2017). Psikologi Keperawatan. Yogyakarta: Pustaka Baru Press.

Feist, J. \& Gregory J.F. (2008). Theories of Personality (Edisi Keenam). Yogyakarta: Pustaka Pelajar.

Fithriyah, L. \& Mohammad J.(2014).Pengantar Psikologi Klinis. Jakarta: Prestasi Pustaka Karya.

Hall, C.S \& Lindzer, G. (1993). Psikologi Kepribadian I Teori-teori Psikodinamika (Klinis). Yogyakarta: Kanisius.

Hamka. (1966). Tafsir Al-Azhar. Jakarta: Panji Masyarakat.

Harris, W. (2013). Mindfulness-Based Existential Therapy: Connecting Mindfulness and Existential Therapy: Journal of Creativity in Mental Health, 8, 349-362.

Herdiansyah, H. (2015). Metodologi Penelitian Kualitatif Untuk Ilmu Psikologi. Jakarta: Salemba Humanika.

Herdiansyah, H. (2014). Metodologi Penelitian Kualitatif untuk ilmu-ilmu sosial. Jakarta: Salemba Humanika.

Herdiansyah, H. (2013). Wawancara, Observasi, dan Focus Groups. Depok: PT RajaGrafindo Persada. Indrawati. (2003). Komunikasi Untuk Perawat. Jakarta: EGC.

Jones, R.N. (2011).Teori dan Praktik Konseling dan Terapi. Yogyakarta: Pustaka Pelajar.

Kowalak, J.P. (2011). Buku Ajar Patofisiologi. Jakarta: EGC.

Matsumoto, D. (2009). The Cambridge Dictionary of Psychology. New York: Cambridge University Press.

Maslow, A. (1970). Motivation and Personality: New York: Harper and Row.

Moleong, L.J. (2017). Metode Penelitian Kualitatif Edisi Revisi. Cetakan Ketigapuluh enam. Bandung:PTRemaja Rosdakarya.

Olson, M.H., Hergenhahn, B.R. (2013). Pengantar Teori- Teori Kepribadian.Yogyakarta: Pustaka Pelajar.

Pieter, H.Z. (2017). Dasar-dasar Komunikasi bagi Perawat. Jakarta: Kencana.

Piroth, L., Callerot, J.Y., Grappin, M. (2015).Therapeutic Trials in HIV Infection: Which Benefit for Which Patients?: HIV Clinical Trials Volume 2. 
Portal Resmi Pemerintahan Kota Palembang. Diakses pada 3Agustus 2018 dari http:/www.palembang.go.id/\#

Reber, A.S. \& Emily S.R. (2010). Kamus Psikologi. Yogyakarta: Pustaka Pelajar.

Sarafino, E.P. (2006). Health Psychology: Biopsychosocial Interactions- Fifth Edition. USA: John Wilet \& Sons.

Shen, Y., Senzer, N., \& Nemunaitis, J. (2005). Individualised cancer therapeutics: dream or reality? Therapeutics Construction: Expert Opinion on Biological Therapy, 5 (11). 1427-1441.

Smith. H.W. 2003. What matters most: Hal-hal yang paling utama. Jakarta: Binarupa Aksara.

Steinhauser, K.E., Alexander, S., Olsen, M.K., \& Stechuchak, K.M. (2017). Addressing Patient Emotional and Existential Needs, During Serious Illness:Results of the Outlook Randomized Controlled Trial: Journal of Pain and Symptom Management, 54 (6). 898-908.

Stuart \& Sundeen. (1995). Buku Keperawatan (Alih Bahasa) Achir Yani S. Hamid. Edisi 3. Jakarta: EGC.

Sudoyo, A.W. (2006). Buku Ajar Ilmu Penyakit Dalam Jilid III Edisi IV. Jakarta: Departemen Ilmu Penyakit Dalam Fakultas kedokteran Universitas Indonesia.

Tacon, A.M. (2011). Mindfulness: Existential, Loss, and Grief Factors in Women with Breast Cancer: Journal of Psychosocial Oncology, 29 (6). 643- 656.

Udo, C. (2014). The concept and relevance of existential issues in nursing, European Journal of Oncology Nursing vol 18, Issue 14. 347-354.

WHO. Global Burden Disease. Diakses pada desember 2016. http://www.who.int/healthinfo/global_burden_disease/GlobalCOD_method2000_2015.pdf?ua=1,

Wilson, P.M \& Apple, S.W. (2013). Existential Counselling and psychotherapy and Maori Clients Asia Pacific Journal of Counselling And Psychotherapy, 4 (2). 137-146

Wong, D.L. (1996). Pedoman Klinis Keperawatan Pediatrik. Jakarta: EGC.

Wulur, M.B. (2015). Psikoterapi Islam. Yogyakar 